\title{
LAPORAN KEUANGAN ORGANISASI NIRLABA (LEMBAGA MASJID)
}

\author{
Pipit Rosita Andarsari \\ STMIK ASIA-Malang \\ pr.andarsari@gmail.com
}

\begin{abstract}
Abstrak
Lembaga Masjid merupakan salah satu bentuk organisasi nirlaba dalam bidang keagamaan, sesuai dengan Pernyataan Standar Akuntansi Keuangan (PSAK) 45 tahun 2011 tentang Organisasi nirlaba, bahwa organisasi nirlaba juga harus dan berhak untuk membuat laporan keuangan dan melaporkan kepada para pemakai laporan keuangan. Untuk itu lembaga masjid harus dan berhak untuk membuat laporan keuangan yang akuntabilitas dan melaporkan kepada pemakai laporan keuangan lembaga masjid. Akuntansi merupakan suatu kegiatan yang dilakukan untuk menghasilkan suatu sistem informasi berupa laporan keuangan yang dibutuhkan oleh berbagai pihak baik pihak internal maupun pihak eksternal organisasi. Kegiatan yang dilakukan dalam proses akuntansi meliputi pencatatan, penggolongan, peringkasan, pelaporan dan penganalisisan data keuangan dari suatu organisasi. Dengan demikian, lembaga masjid memerlukan akuntansi sebagai alat bantu dalam pengelolaan, perencanaan dan pengawasan keuangan dengan berpedoman pada PSAK 45 tahun 2011 tentang Standar Pelaporan keuangan Organisasi Nirlaba yang ditetapkan oleh Ikatan Akuntan Indonesia (IAI) sehingga laporan keuangan yang dihasilkan oleh lembaga masjid dapat dipercaya dan transparan dalam pelaporannya.
\end{abstract}

Kata kunci : Akuntansi, nirlaba, laporan keuangan, lembaga masjid

\section{PENDAHULUAN}

Tingginya tingkat ketidak pastian dan ketidak stabilan lingkungan yang dihadapi oleh berbagai organisasi, maka diperlukan sebuah sistem perencanaan baik dari segi apapun. Peranan akuntansi dalam segi pengelolaan keuangan sebuah organisasipun semakin disadari oleh berbagai pihak, baik organisasi yang berorientasi pada laba maupun non - laba (nirlaba). Jusuf (2005) menyatakan bahwa organisasi nirlaba merupakan organisasi yang tidak mencari laba seperti organisasi keagamaan, yayasan atau lembaga pendidikan. Walaupun organisasi semacam ini tidak mencari laba, namun mereka tetap berurusan dengan soal-soal keuangan karena mereka mempunyai anggaran, membayar tenaga kerja, membayar listrik dan sewa, serta urusan-urusan keuangan lainnya. Disamping itu terdapat karakteristik khusus organisasi nirlaba dalam memperoleh sumberdaya yang dibutuhkan untuk menjalankan aktivitas operasionalnya. Organisasi nirlaba memperoleh sumberdaya dari sumbangan para penyumbang yang tidak mengharapkan pembayaran kembali atau pengembalian manfaat ekonomi yang sebanding dengan jumlah sumberdaya yang diberikan (Ikatan Akuntan Indonesia,2012). Karakteristik khusus ini menimbulkan jenis transaksi, siklus operasi, pola pengelolaan keuangan, perlakuan akutansi dan kebutuhan pelaporan keuangan yang berbeda 
dengan organisasi bisnis pada umumnya.

Masjid merupakan salah satu organisasi nirlaba dalam bidang keagamaan, sesuai dengan Pernyataan Standar Akuntansi Keuangan (PSAK) 45 tahun 2011 tentang Organisasi nirlaba, bahwa organisasi nirlaba juga harus dan berhak untuk membuat laporan keuangan dan melaporkan kepada para pemakai laporan keuangan. Masjid harus membuat laporan keuangan yang akurat dan memberikan informasinya kepada pengguna laporan keuangan tersebut yaitu para donatur masjid. Untuk dapat membuat laporan keuangan dana masjid dengan akurat dibutuhkan penerapan akuntansi, dan peranan akuntansi disini adalah memperlancar manajemen keuangan dalam fungsinya sebagai alat perencanaan, pengawasan dan pengambilan keputusan.

Ketika Nabi SAW. memilih masjid sebagai langkah pertama membangun masyarakat madani, konsep masjid bukanlah hanya sebagai tempat sholat, atau tempat berkumpulnya kelompok masyarakat (kabilah) tertentu, tetapi masjid sebagai majelis untuk memotivasi atau mengendalikan seluruh masyarakat (Pusat pengendalian masyarakat). Secara konseptual masjid juga disebut sebagai Rumah Allah (Baitullah) atau bahkan rumah masyarakat (bait al jami'). (http://www.siperubahan.com/read/436/Ketika-Masjid-Membutuhkan-SentuhanPara-Ekonom-Syariah). Melihat secara umum perkembangan masjid di masa sekarang, terutama dalam hal kepengurusan identik dengan seorang Imam, muadzin, khatib, dan pengurus lain yang sering disebut juga dengan ta'mir masjid. Ta'mir biasanya adalah orang yang sudah sepuh dan tidak memiliki latar belakang keilmuan yang cukup untuk mengelola keuangan secara profesional. Hal ini menimbulkan persoalan ketika dana masjid yang diperoleh dari infaq atau sumbangan para donatur dikelola secara apa adanya tanpa melalui proses pencatatan keuangan yang semestinya.

Banyak masyarakat yang antipati terhadap masjid, dikarenakan pengurus masjid tidak transparan dalan memberikan laporan keuangan dan pengelolaan masjid yang tidak baik menyebabkan jamaah masjid banyak yang keluar. Permasalahan lain yang seringkali muncul yaitu masih banyaknya masjid yang tidak mencatat secara rinci pemasukan dan pengeluaran kas, biasanya hanya dicatat sebatas penerimaan dan pengeluaran kas tanpa merinci sumber pemasukan kas dan penggunaan kas masjid untuk apa saja, sehingga terkadang hal ini menimbulkan kecurigaan di kalangan masyarakat.

Pencatatan keuangan masjid biasanya hanya mencakup penerimaan dan pengeluaran kas masjid saja tanpa memperlihatkan jumlah aset yang dimiliki oleh masjid dan berapa nilainya, sehingga banyak kasus hilangnya aset masjid karena kelemahan sistem pencatatan laporan keuangan. Belum lagi jika antara masjid yang satu dengan yang lainnya terdapat perbedaan yang mencolok, masjid yang satu memiliki dana yang cukup besar sedangkan yang lainnya sangat minim sehingga pengurus masjid harus pontang - panting mencari sumbangan kesana kemari dan hal ini menjadi citra buruk bagi pemeluk agama lain bahwa umas Islam identik dengan peminta - minta. Maka penerapan sistem keuangan yang baik akan memberikan jawaban yang tepat atas ketidakpercayaan masyarakat terhadap organisasi masjid dan takmir/pengurusnya.

\section{TINJAUAN PUSTAKA}

\section{Konsep dasar Akuntasi}


Akuntansi merupakan kegiatan untuk mengolah data - data keuangan menjadi informasi yang siap dipakai oleh pihak yang berkepentingan, dalam hal ini bisa pihak pengelola sebagai alat pengendalian dan juga donatur. Akuntansi merupakan suatu proses yang meliputi kegiatan (1) pencatatan, (2) penggolongan, (3) peringkasan, (4) pelaporan dan (5) penganalisisan data keuangan dari suatu organisasi. Charles T. Horngren, dan Walter T.Harrison (2007:4) menyatakan bahwa Akuntansi adalah sistem informasi yang mengukur aktivitas bisnis, memproses data menjadi laporan, dan mengkomunikasikan hasilnya kepada para pengambil keputusan. (http://www.kompasiana.com/klinikakuntansi/definisi-akuntansimenurut-para-ahli).

Fungsi utama informasi yang dihasilkan oleh penerapan akuntansi adalah pengendalian. Informasi akuntansi merupakan alat pengendalian yang vital bagi sebuah organisasi karena akuntansi memberikan informasi yang bersifat kuantitatif. Informasi akuntansi umumnya dinyatakan dalam bentuk ukuran finansial, sehingga memungkinkan untuk dilakukan pengintegrasian informasi dari tiap-tiap unit organisasi yang pada akhirnya membentuk gambaran kinerja organisasi secara keseluruhan.

\section{Akuntasi Sektor Publik.}

Akuntansi sektor publik adalah akuntansi yang dipakai oleh lembaga-lembaga publik sebagai alat pertanggung jawaban kepada publik. Secara kelembagaan wilayah publik antara lain meliputi organisasi nonlaba pemerintahan dan organisasi nonlaba non-pemerintahan meliputi organisasi sukarelawan, rumah sakit, sekolah tinggi dan universitas, serta organisasiorganisasi non-pemerintahan lainnya (yayasan,lembaga swadaya masyarakat, organisasi keagamaan, organisasi politik, dan lain sebagainya).

\section{Sifat Organisasi Nonlaba}

Organisasi Nonlaba memiliki sektor entiti yang sangat berbeda, dimana pemiliknya adalah publik dan privat, para dermawan dan self promoting, memperoleh pembebasan pajak dan/atau dapat dikenakan pajak. Organisasi Nonlaba adalah salah satu diantara empat kategori : VHWO, rumah sakit, sekolah tinggi dan universitas, dan organisasi Nonlaba lain-lainnya (seperti gereja, masjid, museum, organisasi massa dan lain-lain). Metode-metode akuntansi dan laporan keuangan untuk setiap organisasi Nonlaba berbeda. Organisasi Nonlaba pertama didesain sebagai pemerintahan atau sebagai non-pemerintahan untuk menentukan apakah harus mengikuti standar-standar GASB atau FASB (di Indonesia SAP atau SAK). Semua organisasi nonlaba non-pemerintah esensinya menggunakan basis panduan yang sama, meskipun sifat dari transaksinya berbeda.

Tabel 1: Perbedaan Karakteristik Organisasi Nonlaba dengan Perusahaan Komersial

\begin{tabular}{|l|l|}
\hline Not-For-Profit Entity & \multicolumn{1}{c|}{ Commercial Business Enterprises } \\
\hline $\begin{array}{l}\text { 1. Menerima kontribusi sumber dana } \\
\text { dalam jumlah signifikan dari pemberi } \\
\text { dana yang tidak mengharapkan } \\
\text { pengembalian }\end{array}$ & $\begin{array}{l}\text { 1. Pemberi dana adalah pemilik atau kreditor } \\
\text { yang mempunyai kepentingan untuk } \\
\text { memiliki atau pengembalian tambah } \\
\text { keuntungan atau bunga. }\end{array}$ \\
\hline
\end{tabular}




\begin{tabular}{|l|l|}
\hline $\begin{array}{l}\text { 2. Beroperasi untuk menghasilkan } \\
\text { barang dan jasa yang bukan untuk } \\
\text { mencari laba }\end{array}$ & $\begin{array}{l}\text { 2. Menghasilkan barang dan jasa untuk } \\
\text { menghasilkan laba. }\end{array}$ \\
\hline $\begin{array}{l}\text { 3. Pemberi dana tidak mempunyai } \\
\text { kepentingan terhadap organisasi. }\end{array}$ & $\begin{array}{l}\text { 3. Pemberi dana mempunyai kepentingan } \\
\text { utk memiliki atau pengembalian dana. }\end{array}$ \\
\hline
\end{tabular}

\section{Laporan Keuangan}

Tujuan utama laporan keuangan menurut PSAK No. 45 adalah menyediakan informasi yang relevan untuk memenuhi kepentingan para penyumbang, anggota organisasi, kreditur, dan pihak lain yang menyediakan sumber daya bagi organisasi nirlaba.

Munawir mengatakan "Laporan keuangan merupakan alat yang sangat penting untuk memperoleh informasi sehubungan dengan posisi keuangan dan hasil-hasil yang telah dicapai oleh perusahaan yang bersangkutan. Dengan begitu laporan keuangan diharapkan akan membantu bagi para pengguna (users) untuk membuat keputusan ekonomi yang bersifat finansial.

\section{Gambar 1: Tujuan Laporan Keuangan APB statement No. 4}

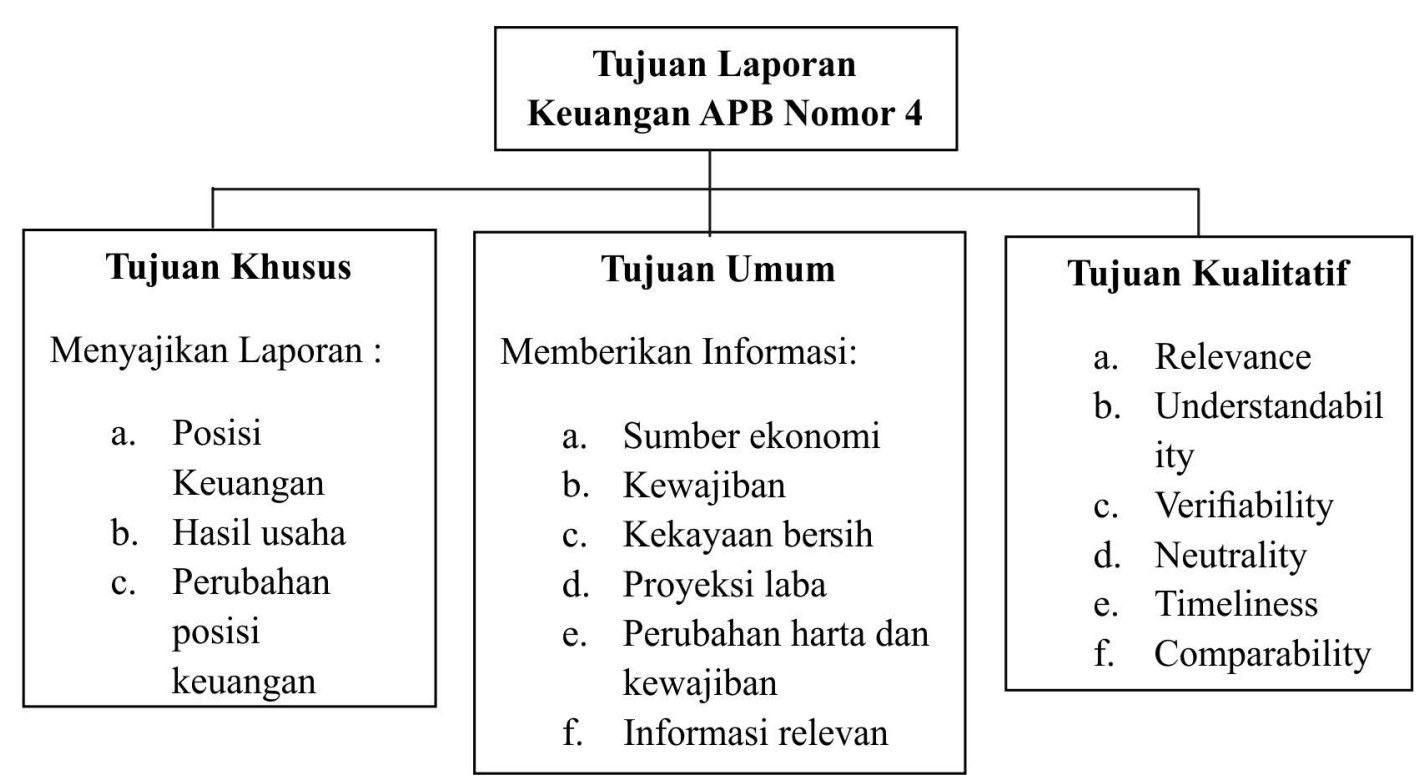

Sumber: Sofyan Syafri Harahap

\section{Laporan Keuangan Organisasi Nirlaba}

Laporan keuangan organisasi nirlaba menurut Pernyataan Standar Akuntansi Keuangan No.45 meliputi:

\section{1) Laporan Posisi Keuangan}

Tujuan laporan posisi keuangan adalah untuk menyediakan informasi mengenai aktiva,kewajiban dan aktiva bersih serta informasi mengenai hubungan antara unsur-unsur tersebut pada waktu tertentu. 


\section{2) Laporan Aktivitas}

Tujuan utama laporan aktivitas adalah menyediakan informasi mengenai pengaruh transaksi dan peristiwa lain yang mengubah jumlah dan sifat aset neto; hubungan antar transaksi dan peristiwa lain; dan bagaimana penggunaan sumber daya dalam pelaksanaan berbagai program atau jasa.

\section{3) Laporan Arus Kas}

Tujuan utuama laporan arus kas adalah menyajikan informasi mengenai penerimaan dan pengeluaran kas dalam suatu periode.

\section{4) Catatan Atas Laporan Keuangan}

Merupakan bagian dari laporan keuangan yang tak terpisahkan karena berisikan penjelasan - penjelasan rinci atas akun - akun dalam laporan keuangan.Organisasi nirlaba menggunakan basis akuntansi akrual untuk mengakui pendapatan dan bebannya.PSAKNo.45 mengelompokkan sumberdaya organisasi nirlaba dalam 4 (empat) kategori yang masing masing tergantung pada ada tidaknya pembatasan:

a. Pembatasan permanen adalah pembatasan penggunaan sumberdaya yang ditetapkan oleh pemberi sumber daya yang tidak mengharapkan pembayaran kembali agar sumber daya tersebut dipertahankan secara permanen, tetapi entitas nirlaba diizinkan untuk menggunakan sebagian atas semua penghasilan atau manfaat ekonomi lain yang berasal dari sumber daya tersebut.

b. Pembatasan temporer adalah pembatasan penggunaan sumber daya oleh pemberi sumber daya yang tidak mengharapkan pembayaran kembali yang menetapkan agar sumber daya tersebut dipertahankan sampai dengan periode tertentu atau sampai dengan terpenuhinya keadaan tertentu.

c. Sumber daya terikat adalah sumber daya yang penggunaannya dibatasi untuk tujuan tertentu oleh pemberi sumber daya yang tidak mengharapkan pembayaran kembali. Pembatasan tersebut dapat bersifat permanen atau temporer.

d. Sumber daya tidak terikat adalah sumber daya yang penggunaannya tidak dibatasi untuk tujuan tertentu oleh pemberi sumber daya yang tidak mengharapkan pembayaran kembali.

\section{Pelaporan Keuangan Masjid}

Masjid merupakan lembaga milik publik yang kepemilikan hartanya merupakan milik umat yang dititipkan kepada para pengelolanya (takmir). Organisasi masjid merupakan organisasi nirlaba ,yaitu dalam menjalankan usaha tidak mencari laba, namun semata - mata hanya untuk melayani kepentingan umat.Modal yang dimiliki oleh masjid biasanya juga cukup besar, terdapat sebidang tanah dan nilai bangunan, juga peralatan dan perlengkapan yang ada di dalam masjid. Sumber pendapatan masjid biasanya terdiri dari Zakat, Infaq, Shodaqoh dan Waqof dan sumber pengeluaran masjid terdiri dari biaya rutin (listrik,air), biaya kebersihan,biaya kegiatan Islami yaitu kegiatan yang dilakukan untuk memperingati harihari besar Islam Maulid Nabi SAW, safari Ramadhan, dan lain sebagainya, dana perbaikan peralatan masjid dll.

Takmir menjalankan perannya berdasarkan kepercayaan umat, maka laporan keuangan yang merupakan bentuk pertanggung jawaban para pengurus masjid atau takmir 
sangat diperlukan untuk memenuhi kepercayaan yang telah diberikan. Laporan oraganisasi Masjid memberikan informasi meliputi :

1. Aset/harta

2. Kewajiban/hutang

3. Ekuitas/modal

4. Pendapatan, dan

\section{Arus Kas}

Dalam PSAK No. 109 tentang akuntansi zakat, infaq/sedekah terdapat beberapa komponen laporan keuangan yang harus dibuat oleh lembaga masjid secara lengkap yang terdiri dari:

1. Neraca (laporan posisi keuangan);

2. Laporan perubahan dana;

3. Laporan perubahan aset kelolaan;

4. Laporan arus kas; dan

5. Catatan atas laporan keuangan

\section{Bentuk Pengelolaan Keuangan Pada Lembaga Masjid}

Terdapat beberapa teknik akuntansi yang dapat diadopsi oleh sektor publik,yaitu : akuntansi anggaran, akuntansi komitmen,akuntansi dana, akuntansi kas dan akuntansi akrual. Kelima teknik tersebut tidak bersifat mutually exclusive.

Proses pencatatan akuntansi pada masjid lebih sederhana dibanding dengan pencatatan akuntansi pada komersial, dalam pencatatan akuntansi masjid langkah yang utama yaitu mengelompokkan sumber pendapatan. Misalnya pendapatan dari ibu pengajian, kegiatan rutin peserta TPA, sumbangan dari donatur dan lain-lain. Pengeluaran untuk kegiatan rutin masjid, kebersihan dan keamanan masjid, keperluan idul adha dan idul fitri serta lain-lain. Dengan adanya pencatatan akuntansi yang jelas antara pemasukan dan pengeluaran maka donatur dan warga sekitar tidak akan bertanya-tanya berapa saldo masjid, berapa jumlah sumbangan dari donatur, dan lain sebagainya.

Pada penerapannya, akuntansi masjid lebih menggunakan metode pencatatan cash basis yakni mengakui pendapatan dan biaya pada saat kas diterima dan dibayarkan. Dengan metode cash basis tingkat efisiensi dan efektifitas suatu kegiatan, program atau aktifitas tidak dapat diukur dengan baik. Akuntansi dengan accrual basis dianggap lebih baik daripada cash basis karena dianggap menghasilkan laporan keuanganyang lebih dapat dipercaya, lebih akurat, komprehensif, dan relevan. Selain itu, akuntansi masjid menggunakan metode pembukuan tunggal (single entry method) dengan alasan lebih praktis dan mudah. Laporan keuangannya disajikan dengan membandingkan antara anggaran yang telah dibuat dengan realisasinya. Kemudian dilaporkan dan dievaluasi dalam periode waktu tertentu. Penggunaansingle entry methodtidak lagi tepat untuk diterapkan karena tidak dapat memberikan informasi yang komprehensif, maka penggunaan single entry method dengan alasan kemudahan dan kepraktisan menjadi tidak relevan lagi. Dan sebaliknya, pengaplikasian pencatatan transaksi dengan sistem double entry mampu menghasilkan laporan keuangan yang auditable dan 
traceable. Sistem pelaporan keuangan pada masjid masih berbentuk format biasa yang sesuai dengan pemahaman mereka. Biasanya hanya berupa pencatatan kas masuk dan kas keluar. Pelaporan keuangan itu sendiri dibuat untuk proses pertanggungjawaban kepada para jama'ah masjid sebagai suatusifat keterbukaan dan transparansinya suatu laporan keuangan.

\section{HASIL DAN PEMBAHASAN}

Berikut Penyajian Laporan Keuangan baik laporan posisi keuangan, laporan aktivitas, laporan arus kas, dan catatan atas laporan keuangan menurut PSAK No. 45 pada lembaga masjid.

1. Laporan Posisi Keuangan

\section{LAPORAN POSISI KEUANGAN \\ LEMBAGA MASJID XYZ \\ PERIODE.}

Aset

Aset lancar

Kas dan setara kas

Piutang

Perlengkapan

XXX

XXX

$\underline{\mathrm{XXX}}$

Total Aset Lancar

XXX

Aset tidak lancar

Tanah

XXX

Bangunan

$\mathrm{XXX}$

Ak. Peny bangunan

$(\mathrm{XXX})$

Peralatan

$\mathrm{XXX}$

Ak. Peny peralatan

$\underline{(\mathrm{XXX})}$

Total Aset tidak lancar

XXX

\section{Total Aset}

Pasiva

Liabilities jk pendek

$\underline{\mathrm{XXX}}$

Total Liabilities jk pendek

XXX

Liabilities jk panjang

$\underline{\mathrm{XXX}}$

Total Liabilities jk panjang

XXX

Aset Neto

Tidak terikat

XXX

Terikat temporer

XXX

Terikat permanen

$\underline{\mathrm{XXX}}$

$\mathrm{XXX}$

Total Aset Neto

$\underline{\mathbf{X X X}}$

Total liabilities dan Aset Neto 
2. Laporan Aktivitas

\section{LAPORAN AKTIVITAS \\ LEMBAGA MASJID XYZ \\ PERIODE .......}

\section{PERUBAHAN ASET NETO TIDAK TERIKAT}

Pendapatan

Sumbangan

XXX

Santunan

$\underline{\mathrm{XXX}}$

Jumlah Pendapatan

XXX

Beban

Bakti Sosial

XXX

Santunan yatim/dhuafa

$\mathrm{XXX}$

Listrik dan air

$\mathrm{XXX}$

Kebersihan

$\underline{\mathrm{XXX}}$

Jumlah Beban

$\mathbf{X X X}$

Kenaikan/penurunan aset neto tidak terikat

XXX

PERUBAHAN ASET NETO TERIKAT TEMPORER

Sumbangan

XXX

Kenaikan/penurunan aset neto terikat temporer

XXX

PERUBAHAN ASET NETO TERIKAT PERMANEN

Sumbangan

XXX

Kenaikan/penurunan aset neto terikat permanen

XXX

KENAIKAN ASETNETO

XXX

ASET NETO AWAL TAHUN

$\underline{\mathrm{XXX}}$

ASET NETO AKHIR TAHUN

XXX 
3. Laporan Arus Kas

\title{
LAPORAN ARUS KAS \\ LEMBAGA MASJID XYZ \\ PERIODE......
}

\author{
AKTIVITAS OPERASI \\ Kas dari penyumbang \\ XXX \\ Kas dari pemberi sumber daya $\quad$ XXX \\ Penerimaan lain-lain $\quad$ XXX \\ Hutang yang harus dilunasi $\quad$ XXX
}

$\begin{array}{rr}\text { AKTIVITAS INVESTASI } & \\ \text { Pembelian peralatan } & \mathrm{XXX} \\ \text { Pembelian investasi } & \mathrm{XXX}\end{array}$

\section{AKTIVITAS PENDANAAN}

Investasi bangunan

XXX

Kenaikan /Penurunan neto investasi dalam kas \& setara kas $\quad$ XXX

Kas dan setara kas awal tahun $\quad$ XXX

Kas dan setara kas akhir tahun $\quad$ XXX

4. Catatan Atas laporan Keuangan

Catatan atas laporan keuangan pada organisasi/lembaga nirlaba memasukkan informasi yang tidak tercantum dalam laporan posisi keuangan, laporan aktivitas dan laporan arus kas.

\section{SIMPULAN DAN SARAN}

Lembaga masjid merupakan organisasi nirlaba yang banyak menghadapi kendala dalam pelaporan keuangannya. Meski bentuknya adalah organisasi nirlaba tetapi PSAK No.45 Tahun 2011 menyatakan bahwa organisasi nirlaba memiliki hak dan harus membuat laporan keuangan. Lembaga masjid dalam pengelolaan keuangannya membutuhkan penerapan akuntansi yang baik sebagai bentuk pertanggung jawaban terhadap para donatur dan masyarakat sekitar yang menjadi jamaah masjid. Laporan keuangan yang terstruktur 
seperti diatur dalam PSAK No. 45 tahun 2011dapat dijadikan panduan untuk menyusun laporan keuangan sehingga laporan keuangan yang dihasilkan akuntable dan lebih transparan. Hal ini juga menjadi jawaban atas ketidakpercayaan masyarakat yang bertanya-tanya tentang laporan keuangan masjid yang selama ini biasanya pencatatannya sangat sederhana dan tidak detil.

\section{DAFTAR PUSTAKA}

Mangkona, Sri Wardhana Saleh, Walaundouw,Stanley Kho. 2015. "Penerapan PSAK No.45 Tentang Pelaporan Keuangan Organisasi Nirlaba Pada Masjid Nurul Huda Kawangkoan”. Universitas Sam Ratulangi Manado. Jurnal EMBA Volume. 3 No. 2.Juni 2015. ISSN $2303-1174$.

Charles T.Horngren dan Walter T. Harrison Jr.2007. Akuntansi Jilid Satu . Edisi Tujuh. Jakarta: Penerbit Erlangga.

Fahmi, Irham. 2013. PENGANTAR MANAJEMEN KEUANGAN. Alfabeta Bandung.

Harahap, Sofyan. 2013. Teori Akuntansi - Edisi Revisi 2011. Penerbit Rajawali Pers, Jakarta

Ikatan Akuntansi Indonesia. 2012. PSAK No. 45 , No. 109. Ikatan Akuntansi Indonesia, Jakarta.

Jusuf, Al. Haryono. 2005. Dasar-dasar Akuntansi. Jilid 1. Sekolah Tinggi Ilmu Ekonomi YKPN, Yogyakarta.

Mardiasmo. 2005. AKUNTANSI SEKTOR PUBLIK. Penerbit Andi, Yogyakarta.

Renyowijoyo, Muindro. 2013. AKUNTANSI SEKTOR PUBLIK. Organisasi Non Laba. Mitra Wacana Media. Edisi 3.

Fatih, Mohammad.2015. "Implementasi Penyusunan Laporan Keuangan Pada Lembaga Nirlaba Yayasan Berdasarkan PSAK 45 (Study Kasus Pada Yayasan Pesantren Global Tarbiyyatul Anfin Kecamatan Pakis Kabupaten Malang)".Skripsi. Fakultas Ekonomi Jurusan Akuntansi Universitas Maulana Malik Ibrahim, Malang. 